of milk, the other leaving these proteins apparently unchanged. Four of the strains examined fell into the first named group, and six into the other group.

In all other respects these strains were identical. Morphologically they were indistinguishable (Fig. 1), and all gave identical fermentation reactions. Thus, all formed acid from dextrin, sucrose, lactose, maltose, glucose, fructose, galactose, mannose, mannitol,

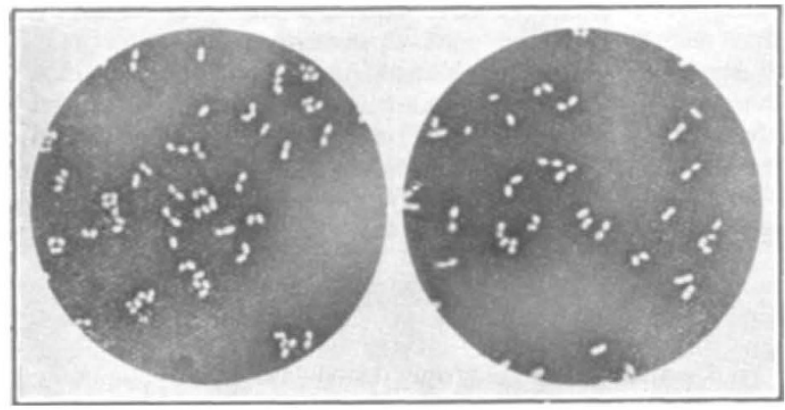

FiG. 1. Two strains of Streptococcus apis which differ solely in their power of liquefying gelatin and coagulating and peptonising milk casein.

glycerol and salicin, and none of them produced acid from starch, inulin, raffinose, arabinose, xylose, inositol, adonitol and erythritol under the experimental conditions. The cultural, morphological and biochemical characteristics of these organisms are being described in detail ${ }^{6}$.

Rothamsted Experimental Station,

H. L. A. TARR. Harpenden, Herts.

Jan. 6.

1 Maassen, A., Arb. Biol. Abt. (Anst. Reichsanst.) Berlin, 6, 53.

${ }^{2}$ White, G. F., Bull. U.S. Dept. Agric., No. 810 (1920).

${ }^{3}$ Borchert, A., Z. Bakt. Abt., (2), 92, 179.

"Bergy, D. H., "Manual of Determinative Bacteriology", Fourth edition. Williams and Wilkins, Baltimore (1934)

'Tarr, H. L. A., Bee Craft, 17, 310 (1935). Archiv. Bienenkunde (in press).

Tarr, H. L. A., Ann. Appl. Biol. (submitted for publication, 1936).

\section{European Species of Fish from the Tavoy Coast, Burma}

EARLY in January 1934, the Zoological Survey of India received for determination an extensive collection of fish from Prof. F. J. Meggitt, of the University College, Rangoon. The major part of the collection was made at Maungmagan, a village on the Tavoy Coast, north-west of Tavoy, Burma. Among the 44 species of fish collected at Maungmagan, there are five forms, Ammodoytes lanceolatus, Le Sauvage, Blennius pholis, Linn., Trachynus draco, Linn., Cottus bubalis, Euphrasen, and Lophius piscatorius, Linn., the range of which is generally believed to be restricted to the Atlantic Ocean, and none of which had previously been recorded from the Indian waters. In passing, it may be mentioned that our specimens were sent to Mr. J. R. Norman of the British Museum (Nat. Hist.), who very kindly confirmed our identifications.

On inquiry, Prof. Meggitt assures us that he had no material of European fishes with him, and in the case of Blennius and Cottus he definitely recalls having collected them himself. The collections of the Zoological Survey of India in the Indian Museum, Calcutta, consist mainly of Indian animals, and there is, therefore, no possibility of any European material having been mixed up with the Burmese collection in our laboratories. Moreover, all the specimens appear freshly preserved. In view of the above, it seems tolerably certain that specimens of the species enumerated above, found in the collection from Maungmagan, were collected in Burmese waters.

With the view of verifying our results, a second collection of fish was procured from Maungmagan through the kindness of Prof. Meggitt. The earlier collection had been made in October 1933, while the second collection was made in January 1935. The fish fauna, according to the collections received, seems to have totally changed with the seasons. Only three well-known species, namely, Terapon jarbua, Sillago sihama and Salarias dussu. mieri, are common in the two collections, and no specimens of any of the European species are present in the second collection. This, however, is not surprising, for the January collection, which consists mainly of coral forms, apparently appears to have been made in coral-reef areas, while the earlier collection was made in sandy, rocky and estuarine pools and the open sea.

The present communication is published with the view of bringing to the notice of European ichthyologists the occurrence of certain Atlantic species in Indian waters; a full report on the fish material from Maungmagan will appear shortly in the Records of the Indian Museum, vol. 38 .

Sunder Lal Hora.

Dev Dev MukerJi.

Zoological Survey of India,

Indian Museum, Calcutta.

Dec. 18.

\section{Thermal Decomposition of Silver Oxalate}

WoRk has been in progress here for some years on the thermal decomposition of silver oxalate, and two papers on the subject are now practically ready for publication. In the meantime, a paper by Benton and Cunningham has appeared ${ }^{1}$, dealing with the influence on this reaction of pre-exposure to light. As it will not be convenient to discuss this paper in our fortheoming publications, we propose to summarise here the points of agreement and difference.

In so far as the experimental results overlap, they are in as good agreement as can be expected from the nature of the reaction. Our conclusions, however, differ in some important respects. Benton and Cunningham, relying on the results obtained with specimens prepared with a slight excess of sodium oxalate, find that the reaction, when unaffected by pre-exposure to light, obeys the equation $d x / d t=k t^{\mathrm{m}}$, where $m$ is about $\mathbf{2 \cdot 5}$. (We are here using the differ. ential form of the equations which appear in their paper, as it affords an easier comparison.) We have shown, however, that the reagent which is in excess at precipitation has a profound influence on the subsequent decomposition, the stability of the specimen being roughly proportional to the logarithm of the nitrate ion concentration. The effect of altering the ionic concentration is illustrated in Fig. 1, which shows the plot of $\log d x / d t$ against $\log t$ for the decomposition of three specimens at $110^{\circ}: G$ is precipitated with a 900 per cent excess of silver nitrate, $B$ with the same excess of sodium oxalate, while $D$, prepared with exactly equivalent quantities, corresponds to the preparations on which Benton and Cunningham rely for their measurement of $m$. 